\title{
Galerijní výstavy a vlastivědná muzea
}

Stanislav Mikule

1 Jiři Žalman nazývá galerijní způsob vystavování formalistickým a muzejní analytickým.

ŽALMAN, Jiři. Kapesní prüvodce po muzeu a muzejnic-

tví. Fiktivní rozhovor Jiřiho

Žalmana s muzejní elévkou. Praha 2016, s. 151.

2 http://www.muzeumlomnice. czl [cit. 6. 12. 2020]

3 https://muzeum.zdarns.czl [cit. 6. 12. 2020]

4 https://www.dkzdar.cz/V\% C3\%BDstavn $\%$ C $3 \% A D \% 20$

s\% C3\%AD\% C5\% $88 \% 20$ Star\% C3\%A9\%20radnice [cit. 6. 12. 2020]

Mgr. Stanislav Mikule Regionální muzeum města Ždáru nad Sázavou stanislav.mikule@zdarns.cz

\section{Gallery Exhibitions and Local History Museums}

Abstract: The paper is based on the author's practice in the Regional Museum in Žd’ár nad Sázavou. In many cities, museums and galleries are located side by side, and museums also hold gallery exhibitions. Museums of local history have considerable potential to supplement such an exhibition with the help of other museum collection objects of a non-artistic nature, such as the document of time of life and work of a given artist or related to the theme of the presented work. This makes the exhibition attractive to a wider range of visitors. The author describes art exhibitions in which collection items from various areas of human activity, realized in the Žd'ár Regional Museum, were connected and presents them as inspiration or a topic to reflect on colleagues from the field who do not yet use the potential of their collection items in a similar spirit.

Keywords: museum presentation, gallery presentation, exhibition, museography

Muzea a galerie tradičně v České republice vnímáme jako odlišné instituce především díky rozdílnému způsobu prezentace exponátů. Galerie jsou muzea umění, jejichž forma prezentace se soustředí na díla samotná, na jejich umělecké působení na diváka. Díla jsou instalována $\mathrm{v}$ různých vzájemných vztazích podle záměrů tvưrce výstavy, ovšem jejich doplnění exponáty neumělecké povahy - vynecháme-li interaktivní prvky - bývá častěji okrajové a mnohdy zcela chybí. Naproti tomu muzejní způsob prezentace - jejíž je galerijní způsob prezentace součástí - je nepoměrně bohatší, protože dưraz na umělecké vyznění díla ustupuje do pozadí a exponát se stává doplňkem vyššího celku jako doklad doby, prostředí apod. Umělecké dílo je tak zasazeno do vztahové linie s mnoha dalšími exponáty neumělecké povahy a záleží jen na autorech výstavy, kterou jeho výpovědní hodnotu se rozhodnou v prezentaci a jejím kontextu umocnit. Zarámované grafiky Karla Němce tak mohou v muzeu sloužit jako výzdoba instalace $\mathrm{v}$ interiéru, přibližující vybavení bytu jejich majitele, na něhož se výstava soustředí, př́padně jako doklad doby, kterou se snaží návštěvníkům přiblížit, ale též jako ilustrační materiál doplňující prezentované etnografické téma atd. ${ }^{1}$

Některé organizace ve svém názvu zahrnují oba výstavní modely - např́íklad Městské muzeum a galerie Lomnice nad Popelkou². Návštěvníka tak nepřekvapí, že se uvnitř setká jak s galerijní formou prezentace, tak s muzejní ve vší její rozmanitosti. Jiné instituce, jako např́klad Regionální muzeum města Žd'áru nad Sázavou, jsou už podle názvu klasickým muzeem³. Galerijní prezentace se $\mathrm{v}$ rámci městských institucí uplatňuje ve výstavních sálech Staré radnice, kde výstavy pořádá př́spěvková organizace Kultura Žd'árt. Pomyslné sféry prezentačních modelů - galerijní a muzejní - jsou tak $\mathrm{v}$ tomto městě rozděleny. Muzeum ovšem čas od času výstavy uměleckých děl také pořádá, zčásti pro různé umělce, zčásti pro díla z vlastní sbírky. Do roku 2010 převládaly klasické formy galerijní prezentace. Pak se ale autor těchto rádků zamyslel nad tím, co dělá muzeum muzeem, č́m se naše muzeum (regionální, tedy vlastivědné) liší od galerií (muzeí umění) a zda-li z těchto možností můžeme těžit a výstavu galerijního typu posunout 
směrem $\mathrm{k}$ výstavám muzejním, aniž bychom ovšem upozad'ovali umělecké hledisko prezentovaných exponátů.

První vlaštovkou se stala výstava „Anton Johann Ferenz" (26. leden - 27. únor 2011), věnovaná 210 . výročí narození ždárského rodáka, tvořícího později ve Znojmě a v Brněs. Pomocí obrazových panelů a sbírkových předmětů $z$ našich fondů byla približžena doba, ve které malîř žil a tvořil. Inscenačním klíčem se stala osoba průvodců, resp. průvodkyň, které $\mathrm{k}$ vystaveným dílům podávaly nejen líčení životních osudů malíře Ferenze, ale přiblížily s pomocí obrazových panelů i díla slavných umělců, kteří Ferenze ovlivnili, vysvětlily například, co se rozumí pod pojmem manýra a především $k$ většině obrazů odvyprávěly př́běh, který se vázal $\mathrm{k}$ portrétovaným osobnostem, $\mathrm{k}$ zobrazeným detailům, $\mathrm{k}$ období, kdy malîr daná díla tvořil či $\mathrm{k}$ jejich pozdějšímu spletitému osudu. Tyto příběhy byly návštěvníkům zpř́stupněny také pomocí popisek a doprovodných textů, a jak je u nás obvyklé, mohli se sami rozhodnout, zda si výklad průvodce přejí či nikoliv. Při této výstavě byla ve žd'árském regionálním muzeu poprvé plně využita síla přiběhů skrytých v obrazech skrze jejich prvořadé pojetí nikoliv jakožto primárně uměleckých děl, ale jako svědků určité doby, muzeálií, nesoucích svá vlastní poselství bez umenšení vjemu jejich uměleckých a estetických kvalit ${ }^{6}$.

Kolegyně Kamila Dvořáková ve své výstavě děl ždárského rodáka, nazvané "Josef Kosinka - Doma i na cestách" (9. července - 29. zář́i 2013), zúročila nejen vlastní zkušenosti a znalosti malířky a ilustrátorky, ale také poznatky z jiných muzeí a $\mathrm{z}$ vlastní průvodcovské praxe ${ }^{7}$. $Z$ pozůstalosti rodiny Bödefeld (dcery Josefa Kosinky) vybrala dva tématické okruhy obrazů. K nim připojila mistrův poutavý životopis, zahrnující úspěšnou kariéru motocyklového závodníka, řidiče taxíku, partyzánské spojky, akademického malíre, ředitele muzea, amatérského fotografa a výrobce domácích ovocných vín. Obrazy tak doplnily jeho fotografie, a protože nemáme zachovanou žádnou osobní upomínku na tohoto umělce, tak alespoň rámcové ukázky malî̌rských

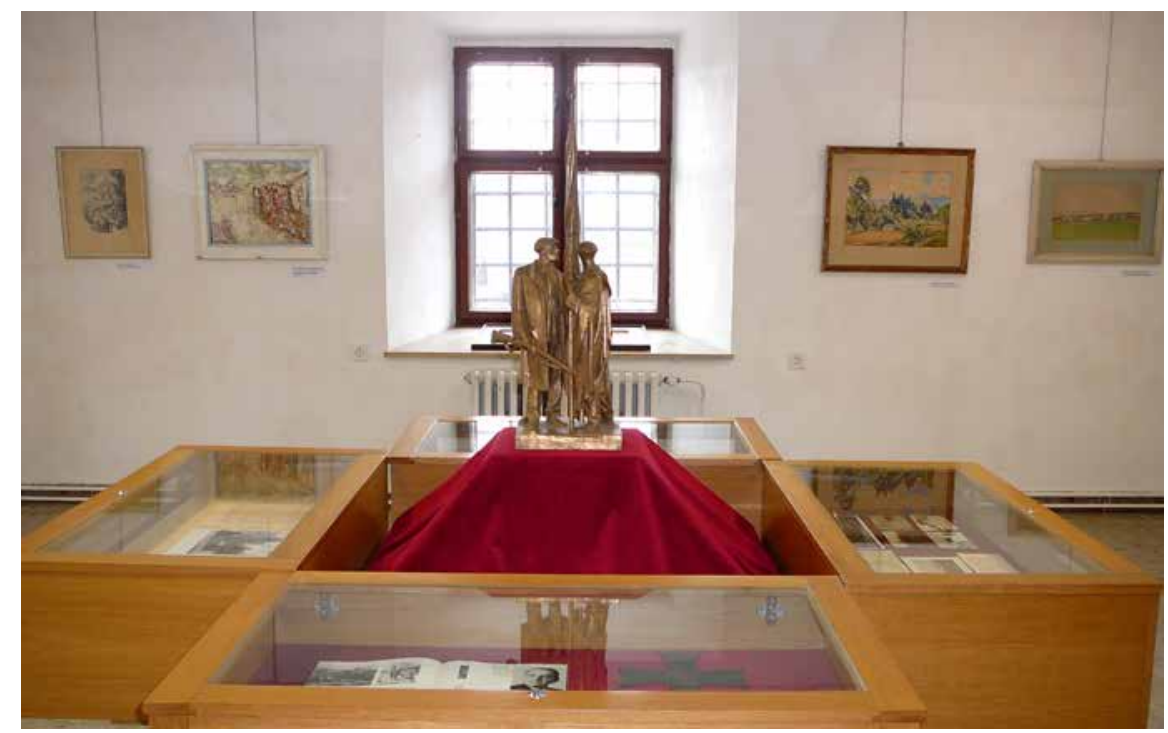

Bud'te v obraze

potřeb. Všechny obrazy se pojily s př́běhy, např́íklad o možnostech cestování do zahraničí v předlistopadové éře, kdy rodina Kosinkova aktivně pomáhala získat potřebná povolení těm, kteří měli s vycestováním problémy, či vyprávění o slavném ostrovu Mont-Saint-Michel.

Zcela nadřadit muzealitu uměleckých děl jejich estetické hodnotě a přitom ji neupozadit bylo ve žd’árském regionálním muzeu rozhodnuto při plánování výstavy "Bud'te v obraze“ (28. ledna - 12. dubna $2020)^{8}$. Klíčem $\mathrm{k}$ výběru prezentovaných exponátů byla míra a různost forem sdělení v nich obsažených. Celá výstava byla pojata ryze sémioticky, jako hrátky se slovy, symboly a volnými asociacemi. Některé byly zřejmé, kupř́kladu u nedatovaného akvarelu Václava Jíchy (1874-1950) „Letní krajina s chalupou" šlo o novou lokalizaci zobrazeného plenéru, představujícího domek na okraji obce Stržanov se ždárskou dominantou v pozadí - Santiniho poutním kostelem sv. Jana Nepomuckého na Zelené hoře, která byla $\mathrm{v}$ době vzniku obrazu ještě zarostlá lesem. Akvarel Václava Süsse „Žd'árská humna u Starého nádraži“ z roku 1908 zachytil kromě jiného i výtopnu parních lokomotiv. O ni se opřel i výklad, doplněný dobovými fotografiemi ždárských železničářu, přezdívaných "frajě̌i", historickým jízdním řádem a vysvětlením, proč se lokomotivám řady 97, které byly ve výtopně nejčastěji, říkalo Kafemlejnek. Olej na lepence Františka Bílka „U Pilského rybníka“ z roku 1945 přiblížil kromě podoby ždárské vodní nádrže po druhé světové válce i tehdejší situaci muzea, které na konci války vyhořelo
5 MIKULE, Stanislav.

Regionální muzeum města Ždáru nad Sázavou v roce 2012. In: Západní Morava, 17, 2013 , s. $142-145$. Fotogalerii z výstavy a její stručný popis naleznete také na internetové stránce muzea: https:// muzeum.zdarns.czlfotogalerie/ anton-johann-ferenz-26-ledna-27-unora-2011 [cit. 6. 12. 2020] Výstavu pripravil Stanislav Mikule.

6 Aneb autentické „věci dotýkané", jak je výstižně a pritom poeticky nazval Jiři Žalman. ŽALMAN, Jiři. Kapesní prùvodce po muzeu a muzejnictví, s. 37.

7 MIKULE, Stanislav.

Regionální muzeum města Ždáru nad Sázavou $v$ roce 2013. In: Západní Morava, 18, 2014, s. 326-330. https:// muzeum.zdarns.cz/fotogalerieljosef-kosinka-doma-i-na-cestach-9-7-29-9-2013 [cit. 6. 12. 2020] Výstavu pripravila Kamila Dvořáková.

8 https://muzeum.zdarns.czl fotogalerie/budte-v-obraze-28.-1.-e28093-12.-4.-2020 [cit. 6. 12. 2020] Výstavu pripravil Stanislav Mikule. 


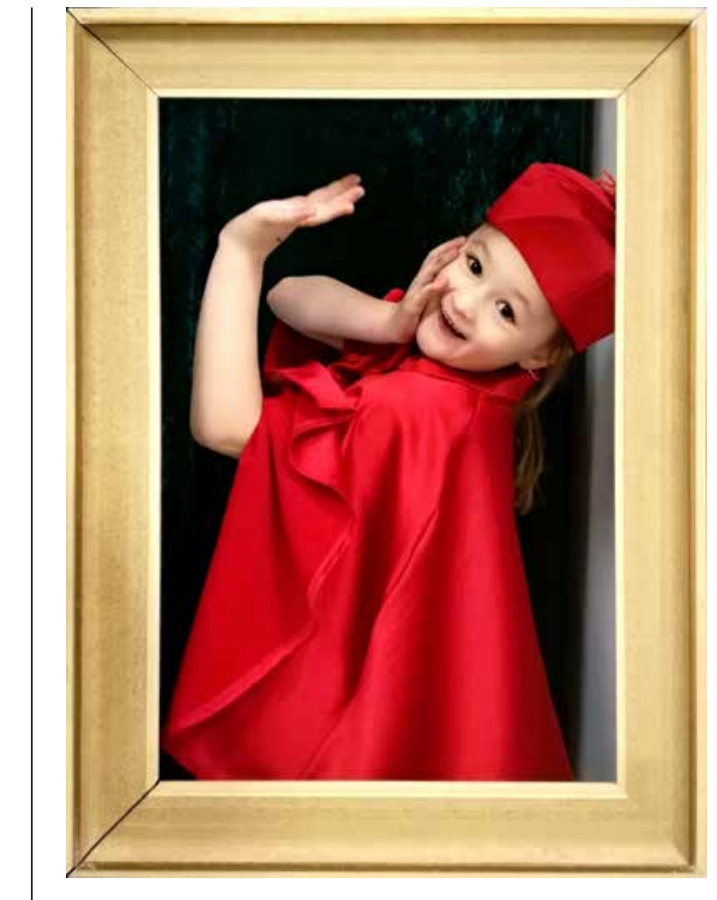

\section{Bud'te v obraze}

a tím přišlo o své sbírky; Bílek zde maloval jako žák pod vedením Otakara Nejedlého a své dílo daroval muzeu jako př́spěvek pro jeho obnovení, spolu s ním tak učinil i Jaroslav Baumbruck. Dosud nevystavený nedatovaný pastel na papíře Františka Hoplíčka "Ve chlévě“ doplnily nejenom originály volských a koňských podkov, aby si zvláště děti uvědomily jejich rozdíl, ale také vyprávění o vzniku českého strakatého skotu s pro mnohé zajímavým zjištěním, že jde o plemeno poměrně mladé, přičemž do poloviny 19. století našim chlévům dominovaly české červinky. Na olejomalbě na plechu, znázorňující sv. Františka z Pauly, stejně jako na oleji na plátně, zpodobňujícím důstojníka ze druhé poloviny 18. století (díla neznámých umělců), se návštěvníci seznámili s podstatou jevu pareidolie, díky níž nám náhodné tvary a shluky bodů připomínají lidské tváře, at' už v těchto dílech, nebo ve fotografii povrchu Marsu. Podrobného rozboru se dočkaly například barokní obrazy „Fons pietatis" či portrét opata Václava Vejmluvy od Simoneho Gionimy, čímž nabídly návštěvníkům možnost nahlédnout do myšlení a vnímání světa našich předků před třemi staletími. $\mathrm{V}$ závěru výstavy byla prezentována díla, která spojovala osoba restaurátorky Hedviky Böhmové-Hájkové a její poutavý životní příběh, zahrnující i odsun po druhé světové válce a následný návrat zpět do republiky $\mathrm{v}$ důsledku prímluv českých kunsthistoriků.

Z běžného rámce volných asociací poněkud vybočoval olej na lepence Jana Konůpka z roku 1935 v první části výstavy, zobrazující hrad Házmburk. Tam nás vyprávění zavedlo až ke sci-fi př́iběhu Jaroslava Bočka "Polka pro astrální ženu“, jehož děj se odehrává na tomto hradě - originál knihy byl samozřejmě na výstavě také prezentován9. Překvapivě živý ohlas mělo povídání u nedatovaného akvarelu Karla Svolinského „Kvočna s kuřaty“, které obsáhlo i evangelickou modlitbu, Karafiátovy broučky a úvahu nad tím, jak by mohlo chutnat grilované tyranosauř́ stehýnko.

Obrazy se prezentovaly klasickou galerijní metodou, trojrozměrné sbírkové předměty, které je doplňovaly (podkovy, kovový artefakt ze zelenohorského kostela, litinové sbírkové předměty nalezené ve spáleništi muzea v roce 1945 apod.), byly umístěny ve vitrínách ve volném prostoru uprostřed sálů a v oknech, zkrátka tam, kde nenarušovaly působení obrazů na návštěvníka jakožto uměleckých děl. Vše doplňovala část přibližující různé významy a užití slova "obraz" a samožrejmě též interaktivní prvky, z nichž nejúspěšnější byly vedle kvízu a možnosti vlastní tvorby prázdné rámy, ve kterých se mohli návštěvníci vyfotografovat $\mathrm{v}$ dobových kostýmech a stát se tak doslova „obrazem“. V rámech byly i všechny výstavní texty, nahrazující klasické popisky.

Slibně se vyvíjející návštěvnost výstavy přerušilo uzavření muzea $\mathrm{v}$ důsledku pandemie koronaviru. Během této nucené pauzy probíhaly v muzeu rekonstrukční práce. Po jejich ukončení mi byla poskytnuta možnost realizovat další výstavu děl z naší sbírky umění. Nazvali jsme ji „Plamenům navzdory" (2. června - 2. srpna 2020) a věnovali ji pětasedmdesátému výročí požáru žd’árské tvrze, $\mathrm{v}$ níž $\mathrm{v}$ roce 1945 sídlilo a v dnešní době po takřka čtyricetileté pauze opět sídlí naše muzeum ${ }^{10}$. 
Zaměřila se na př́tomnost obrazů na tvrzi před požárem a po něm. Středobodem první části výstavy se staly dva obrazy Josefa Kosinky - „Hořící tvrz" a „Tvrz po požáru“. První dílo bylo vystaveno ve vitríně spolu s předměty nalezenými $\mathrm{v}$ troskách tvrze a válečnými artefakty, druhé doplnily nové prírůstky do muzea po požáru včetně díla Baumbruckova a Bílkova a dobové dokumenty, komentující muzejní katastrofu. K nim patřil i pozůstatek údajných stradivárek, jejichž podstatná část podlehla ohni sice za jiných okolností, ale v týchž dnech jako muzeum a také rukou německého vojáka. Díla nalevo (proti doporučenému směru prohlídky) od středobodu zachycovala Zđ'ár před požárem, díla napravo po požáru. Tak mohli návštěvníci sledovat změnu podoby našeho města. Obrazy doplňovaly plastiky Julia Pelikána, Jana Růžičky, Jana Štursy a Antonína Kotrby, opět řazené podle předpokládané doby svého vzniku.

Ve druhé části výstavy, zaměřené na zajímavosti z muzejní sbírky, bylo prezentováno nejvíce nových, dosud nevystavených akvizic. Zastoupení zde měli ždárský Anton Johann Ferenz, malíri Vysočiny (např́klad Alois Lukášek, Jan Odvárka, Pavel Kopáček, Alois Lukášek, Jindřich Zezula) a obraz sv. Volfganga, který se do muzea dostal odkudsi ze Sudet po druhé světové válce a jehož př́iběh se vázal $\mathrm{k}$ aktuálnímu 75. výročí konce války. Díky skladateli Františku Drdlovi, ždárskému rodákovi, naše muzeum získalo také celou řadu uměleckých děl z jeho pozůstalosti. Spolu $s$ umělcovým křeslem, pamětními stuhami či bustou od Julia Pelikána tak byly v zákoutí připomínajícím hudebníkův pokoj vystaveny olejomalba jeho otce, litografie Liszta a Beethovena, Lunardiho sochy Brahmse a Wagnera či Drdlův obraz od Toma von Dregera (který portrétoval např́íklad poslední dva rakousko-uherské vládce) z roku 1936.

Pandemie překazila také konání Dne Ždáru, kterým si Žd'ár mimo jiné připomíná své povýšení na město 11 . června 1607 kardinálem Ditrichštejnem. Této události byla věnována poslední část výstavy, kde se prezentovaly informace

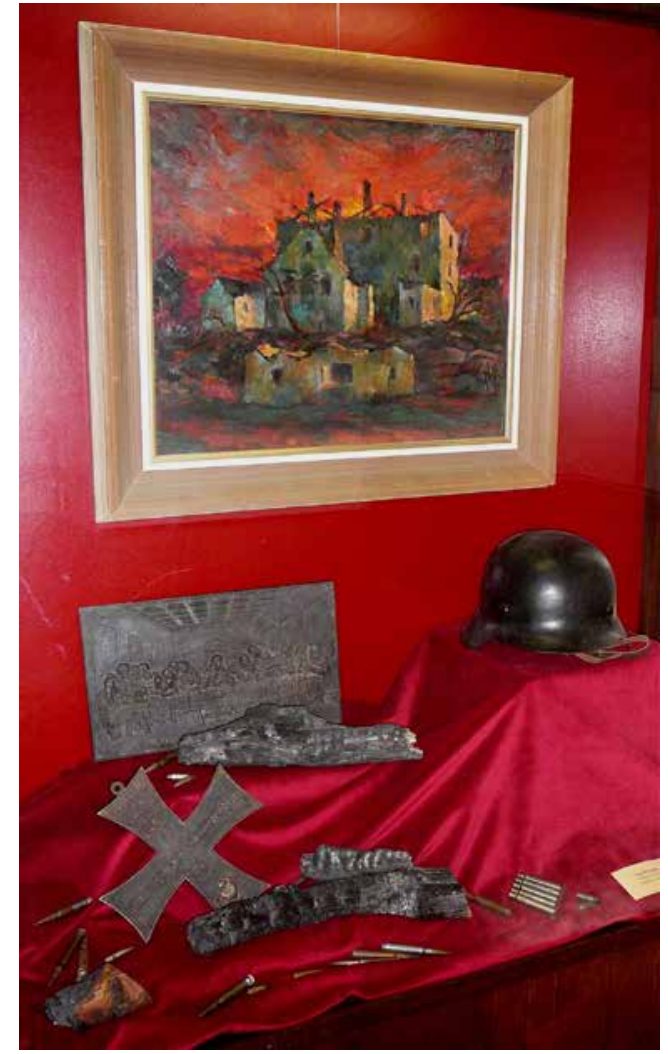

Plamenům navzdory

o povýšení, kardinálův portrét včetně kopie kardinálského oděvu, sádrový odlitek Ditrichštejnovy renesanční mramorové erbovní desky, kterou v roce 1946 provedl Jan Růžička, miniatury a díla umělců ze 17.-19. století. Některá z prezentovaných děl byla zcela nově určena - at' už šlo o olejomalbu "Adorace Krista" s králem Davidem, Janem Křtitelem, Marií Magdalenou a svatými Petrem a Pavlem (dříve „Klanění tří králů“ či „Svatá rodina“), mědiryt "Přenesení sv. Kateřiny“ podle obrazu Heinricha Mückeho (18061891, dříve "Nanebevzetí P. Marie“), rytinu na textilii "Sv. Bernard z Clairvaux" (dřive "Světec") nebo drobnou olejomalbu „Bitva u Budyšína“ (dřive „Bitva“) s Napoleonem Bonapartem.

Na rozdíl od předchozí výstavy byl v této kladen větši dưraz na umělecké a estetické hodnoty. Přesto prezentovaná díla - kde to bylo možné a hlavně vhodné - doplnily další sbírkové předměty z naší muzejní sbírky (předměty z požářiště, erbovní 


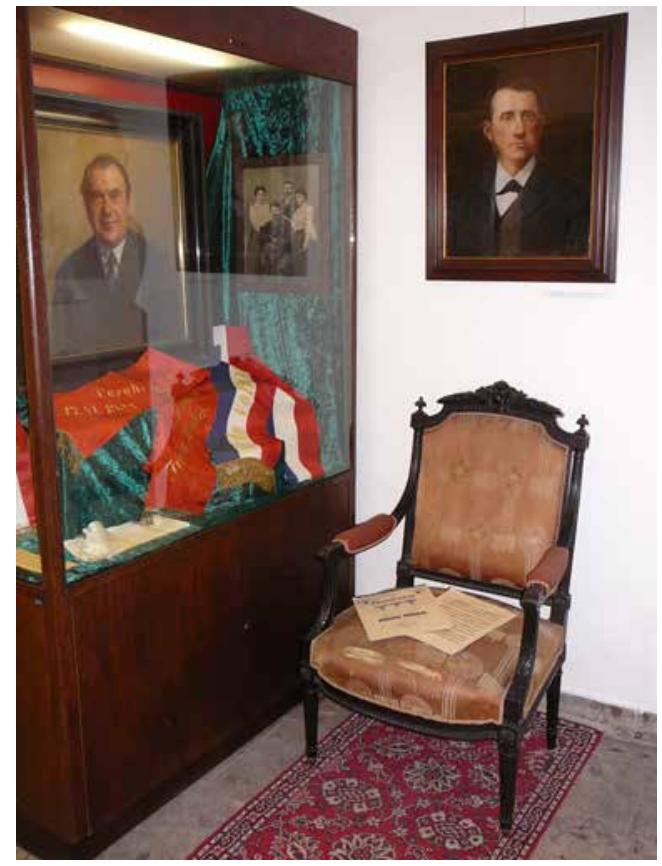

Plamenům navzdory

deska, mobiliáŕ z Drdlovy pozůstalosti). Samozřejmě, že tímto způsobem doplňují své výstavy i mnohé galerie, ale zastávám názor, že $\mathrm{v}$ př́padě muzeí by doplnění uměleckých děl sbírkovými předměty, nepřesně řečeno "neumělecké“ povahy, mělo být samozrejmostí. Do muzea umění jde návštěvník v první řadě za uměleckým zážitkem, od muzea vlastivědného však očekává ještě něco navíc, setkání s tím prapůvodním muzejním fenoménem $\mathrm{v}$ jeho nejčistší podobě, v navázání subjekto-objektového vztahu s muzeálií. Některá muzea tak činí, jiná nikoliv a spokojí se s pouhou galerijní prezentací. To samozřejmě není špatně (zvlášt', když autor výstavy opravdu hodlá prezentovat především umělcovo dílo), ale zůstává tak nevyužit potenciál našeho vlastního specificky muzejního know-how, které nás činí v očích návštěvníků aatraktivními.

Tímto prríspěvkem nechci tvrdit, že jsem objevil Ameriku, jen bych rád k podobnému kroku motivoval i ta muzea, která se $\mathrm{k}$ němu ještě neodhodlala. Jeho důsledkem je totiž zvýšený zájem o výstavu i u návštěvníků, které by „obyčejná" prezentace uměleckých děl nezaujala. Odhalováním skrytých významů, symbolů a asociací $\mathrm{v}$ uměleckých dílech můžeme podnítit zájem o umění u návštěvníků, které by to jinak nenapadlo. Nebude jich mnoho, to si nenamlouvám, ale každá "duše" se přeci počía - především ve výkazech pro naše zřizovatele. K posouzení „,úspěšnosti“ muzeí $\mathrm{v}$ očích některých zřizovatelů totiž kromě kvality výstav hraje nezanedbatelnou roli návštěvnost. Muzejníci se pak přirozeně snaží vyhovět svým chlebodárcům. Někdy se pouští do zatraktivnění výstav pomocí interaktivních prvků tak horlivě, až tyto prvky - zvláště jsou-li moderní, blikající a zárící - změní muzejní výstavu v zábavní podnik, jakýsi Disneyland. Na Disneylandu také není nic špatného, ale není to muzeum a muzeum by touto cestou jít nemělo. Setkal jsem se s tímto nešvarem $v$ roce 2010 tam, kde bych ho nečekal - v Londýně v Natural History Museum, kde v expozici druhohorních obratlovců na člověka číhal průhledný tubus s plyšovými dinosaury, řvoucí umělohmotný tyranosaurus a do tmavého rožku u východu z expozice vměstnaný exponát slavného zubu iguanodona. Naše okouzlení moderními prvky přitom nevede vždy $\mathrm{k}$ požadovanému efektu. Zatímco ještě pro mou generaci, navštěvující základní školu v 80. letech minulého století, jsou dotykové obrazovky a počítačové simulace zajímavé, mladší generace již vyrostly s tablety a chytrými mobily $\mathrm{v}$ kočárcích, a považují je za samozřejmý standard. Když ale mladí návštěvníci dostali $\mathrm{v}$ dnes již zrušeném ždárském Muzeu knihy možnost nahlédnout do barokního atlasu či vytisknout si pamětní list na tiskařském lisu, zaujalo je to víc než to, co už znali ${ }^{11}$. A zde leží muzejní know-how, kterým oplývají i malá muzea, jež se často trápí nedostatkem financí potřebných pro nejmodernější prezentace. Nemohu-li výstavu obrazů v muzeu doprovodit aplikací pro chytré telefony či počítačovou prezentací, mohu ji doplnit nečekanými informacemi, dobovými fotografiemi daných míst, poutavými komentáŕi o autorech, předměty z majetku autorů či vlastníků vystavených děl nebo jednoduchou interiérovou instalací díla pomocí dobových muzejních sbírkových předmětů, kterýmžto způsobem bylo v rámci vánoční výstavy „Když stromeček zazáríi” (10. prosince 2019 - 12. ledna 2020), věnované oslavám těchto svátků v 70. a 80. letech 20. století, užito např́íklad díla ždárského malíře a grafika Miroslava Roštínského $\mathrm{v}$ rámci vybavení dobové kanceláře, připravené na vánoční večírek ${ }^{12}$. 
Tím může výstava zaujmout i další okruh návštěvníků, s nímž by se v případě čistě galerijní prezentace nepočítalo. Důležitá je však jasná představa autora výstavy, co přesně chce návštěvníkům sdělit výstavou jako celkem, aby pak nebyly zajímavosti $\mathrm{k}$ dílům přiřazovány násilně.

\section{Literatura}

BENEŠ, Josef. Muzeum a sbirky. Praha: Ústav pro informace a řízení v kultuře, 1977.

BENEŠ, Josef. Základy muzeologie. Opava: Open Education \& Sciences pro Ústav historie a muzeologie Filozofickopřírodovědecké fakulty Slezské univerzity, 1997.

BRABCOVÁ, Alexandra (ed.). Brána muzea otevřená. Náchod: Juko a Nadace Open Society Fund, 2003.

MIKULE, Stanislav. Nová muzejní expozice ve Žd'áře nad Sázavou. Muzeum: Muzejní a vlastivědná práce, roč. 52, č. 2 (2014), s. 54-58.

MIKULE, Stanislav. Regionální muzeum města Žd'áru nad Sázavou v roce 2012. In: Západní Morava, roč. 17 (2013), s. 142-145.

MIKULE, Stanislav. Regionální muzeum města Žd'áru nad Sázavou v roce 2013. In: Západní Morava, roč. 18 (2014), s. 326-330.

SÝKOROVÁ, Lenka. Nezávislé kurátorství ve volném čase: Nezávislý kurátor a umělec-kurátor na české vizuální scéně 20002016. Ústí nad Labem: Fakulta umění a designu Univerzity J. E. Purkyně, 2017.

WANČOVÁ, Nina. Využívání nových médii, technologii a moderních prezentačních postupi v českých muzeích. Muzeum: Muzejní a vlastivědná práce, roč. 56, č. 1 (2018), s. 24-36.

WEIDACHER, Friedrich. Príručka všeobecnej muzeológie. Bratislava: Slovenské národné múzeum, 1999.

ŽALMAN, Jiří. Kapesní průvodce po muzeu a muzejnictví. Fiktivní rozhovor Jiř́ho Žalmana s muzejní elévkou. Praha: Národní muzeum, 2016.

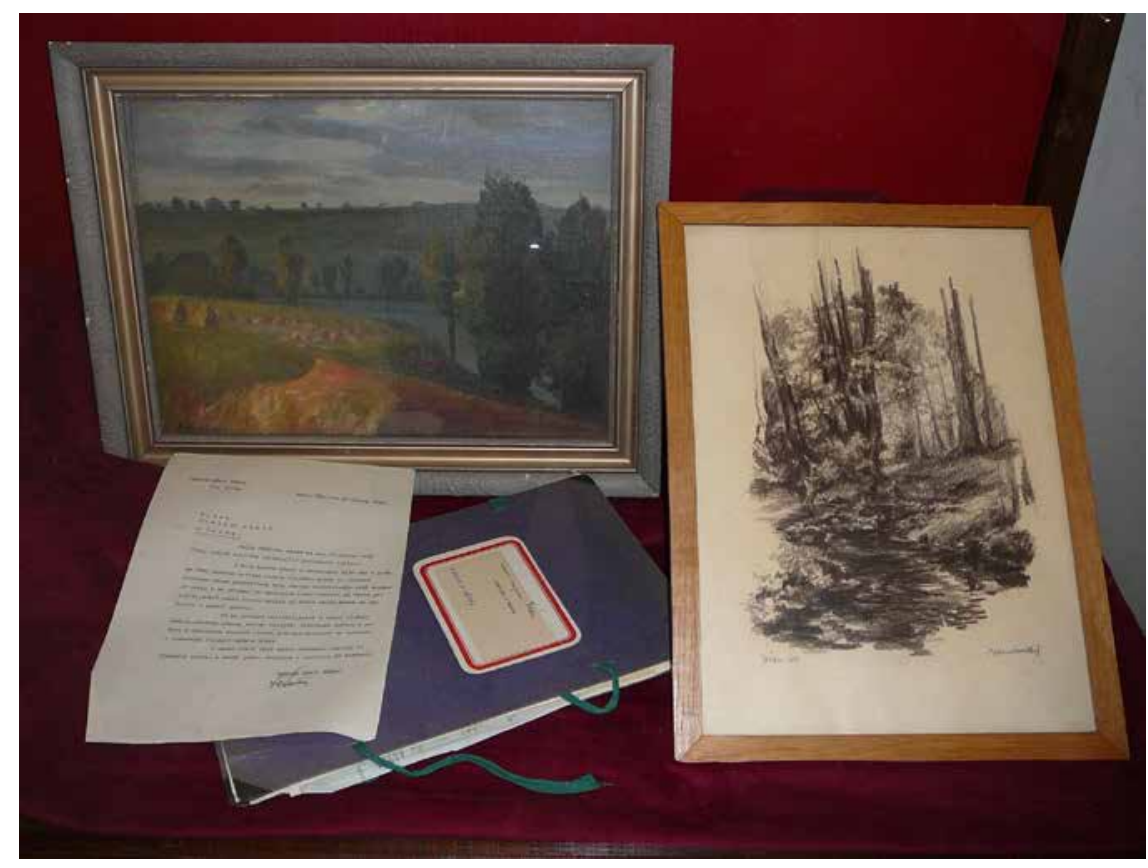

\section{Internetové zdroje}

Anton Johann Ferenz (fotogalerie z výstavy) [cit. 6. 12. 2020], dostupné z https:// muzeum.zdarns.cz/fotogalerie/anton-johann-ferenz-26-ledna-27-unora-2011.

Bud'te $\mathrm{v}$ obraze (fotogalerie $\mathrm{z}$ výstavy) [cit. 6. 12. 2020], dostupné z: https:// muzeum.zdarns.cz/fotogalerie/budte-v-obraze-28.-1.-e28093-12.-4.-2020 Městské muzeum a galerie Lomnice nad Popelkou [cit. 6. 12. 2020], dostupné z: http://www.muzeumlomnice.cz/.

Josef Kosinka - doma i na cestách (fotogalerie z výstavy) [cit. 6. 12. 2020], dostupné z: https://muzeum.zdarns.cz/ fotogalerie/josef-kosinka-doma-i-na-cestach-9-7-29-9-2013

Když stromeček zazáří (fotogalerie z výstavy) [cit. 6. 12. 2020], dostupné z: https://muzeum.zdarns.cz/fotogalerie/kdyz-stromecek-zazari-10.-12.-2019-e28093-12.-1.-2020.

KulturaŽd’ár,p.o.[cit.6.12.2020],dostupnéz: https://www.dkzdar.cz/V\%C3\%BDstavn\%C3\%AD\%20s\%C3\%AD\%C5\%88\%20 Star\%C3\%A9\%20radnice.

Plamenům navzdory (fotogalerie z výstavy) [cit. 6. 12. 2020], dostupné z: https:// muzeum.zdarns.cz/fotogalerie/plamenum-navzdory-2.-6.-e28093-2.-8.-2020.

Regionální muzeum města Žd’áru nad Sázavou [cit. 6. 12. 2020], dostupné z: https://muzeum.zdarns.cz/.
Plamenům navzdory

12 https://muzeum.zdarns. cz/fotogalerie/kdyz-stromecek-zazari-10.-12.-2019-e28093-12.-1.-2020 [cit. 6. 12. 2020] Výstavu pripravili Miloslav Lopaur a Kamila Dvoráková. 